\title{
Elective and emergency laparoscopic cholecystectomy in the elderly: our experience
}

\author{
Alessia G Ferrarese ${ }^{*}$, Mario Solej ${ }^{\dagger}$, Stefano Enrico ${ }^{\dagger}$, Alessandro Falcone ${ }^{\dagger}$, Silvia Catalano ${ }^{\dagger}$, Giada Pozzi ${ }^{\dagger}$, \\ Silvia Marola ${ }^{\dagger}$, Valter Martino ${ }^{\dagger}$ \\ From 26th National Congress of the Italian Society of Geriatric Surgery \\ Naples, Italy. 19-22 June 2013
}

\begin{abstract}
Background: We aimed to analyze outcomes of early and delayed laparoscopic cholecystectomy in the elderly in our General Surgery Division.

Methods: We analyzed 114 LC performed from the 1st of January 2008 to the 31st of December 2012 in our General Surgery division: 67 LC were performed for gallbladder stones and 47 for acute cholecystitis.

Results and discussion: Comparison between Ordinary and Emergency groups showed that drain placement and post-operative hospital stay were significatively different. There were no significative differences between Early Laparoscopic Emergency Cholecystectomy (E-ELC) and Delayed Laparoscopic Emergency Cholecystectomy (D-ELC). There weren't any differences about Team's evaluation.

Conclusion: We consider LC a safe and effective treatment for cholelitiasis and acute cholecystitis in Ordinary and Emergency setting, also in the elderly. We also demonstrate that, in our experience, LC for AC is feasible as well.
\end{abstract}

\section{Background}

Laparoscopic cholecystectomy (LC) represents the gold standard treatment for cholelithiasis.

Its application gradually extended to acute cholecystitis (AC) also in the elderly. We aimed to compare outcomes of the University Section of General Surgery in "San Luigi Gonzaga" Hospital of Orbassano (Turin) with literature, evaluating timing and technique of early or delayed laparoscopic cholecystectomy in the management of acute cholecystitis in elderly patients.

\section{Methods}

From the 1st of January 2008 to the 31st of December 2012, 114 LC were performed at the University Section of General Surgery in elderly patients (Age $>65 \mathrm{yrs}$ ): 67 for gallbladder stones and 47 for acute cholecystitis. The diagnosis of cholecystitis and gallbladder stones was performed

\footnotetext{
* Correspondence: alessia.ferrarese@gmail.com

+ Contributed equally

University of Turin, Department of Oncology, School of Medicine, Teaching Hospital "San Luigi Gonzaga", Section of General Surgery, Orbassano, Turin,
} Italy

C 2013 Ferrarese et al; licensee BioMed Central Ltd. This is an open access article distributed under the terms of the Creative Commons Attribution License (http://creativecommons.org/licenses/by/2.0), which permits unrestricted use, distribution, and reproduction in any medium, provided the original work is properly cited. basing on general conditions, physical examination, laboratory exams, radiologic findings and sepsis score. For the study we also considered: total hospital stay, time before and after surgery, duration and kind of operation, conversion to open procedure, drain and final pathological results. We excluded 29 patients from the study (17 for choledocolytiasis associated and 12 for hospitalisation $>20$ days). We didn't exclude ASA III and ASA IV patients: in these patients (27,4\%, 17 ASA III and 4 ASA IV) we used abdominal pressure not superior of $10 \mathrm{mmHg}$ [1]. We included in the study 85 elderly patients ( 49 M, 36 F): Ordinary Cholecystectomy was peformed in 45 cases (Ordinary Group) and Emergency Cholecystectomy in 40 cases (Emergency Group). This last group was further divided in two groups [2-4]: E-ELC (31 patients with surgery performed before 72 hours from starting of the symptoms) and D-ELC, ( 9 patients with surgery performed after 72 hours until 9 day). The experience of the first operator was also considered a contributing factor. Basing on this factor, and considering laparoscopic learning curves as described in literature (29-40), we identified three subgroups of surgery teams (Table 1) in order to evaluate our results [5-11].

\section{Biomed Central}


Table 1 Definitions of team according to the experience of the lead surgeon

\begin{tabular}{ll}
\hline Team 1 & More than 100 laparoscopic cholecistectomy and more than 100 other laparoscopic operations. \\
\hline Team 2 & Less than 100 laparoscopic cholecistectomy and less than 100 other laparoscopic operations. \\
\hline Team 3 & Surgeons in learning curve progression or Resident with expert Surgeon supervisor \\
\hline
\end{tabular}

Statistical proportions related to the analyzed dichotomic variables, for both E-ELC and D-ELC (gender distribution in different patient groups, number of post-operative complications, conversion rate, number of drains, number of other related surgeries, presence of fever, wall thickening, effusion amount, gallbladder distension and calculosis type) were compared using Chi-square test and Fisher's exact test. Continuous variables like age distribution, postoperative hospital stay time, surgery duration and several haematochemical characteristics (WBC, CRP) were expressed as average (range) and analyzed using the MannWitney U test. Patient distribution according to different surgical teams was confirmed. All statistical analyses were performed using $\mathrm{R}$ software (version 2.6.2), and a $p$ value of less than 0.01 was considered indicative of statistical significance.

\section{Results and discussion}

In our experience, the comparison between Ordinary and Emergency Group was no statistically significant about blood test values and ultrasonographic evidence (Table 2).

We analyzed E-ELC and D-ELC data without finding any statistically significant difference in the elderly, except for the full hospital stay duration, which was longer for D-ELC patients (Table 3). Operation time, conversion rate, and complications did not demonstrate any significant difference between the two groups. Comparison of success rates achieved by different surgeons yielded the same results, regardless of their levels of experience (Table 4). Patients can be operated after a time interval of 73 hours and up to 9 days, and receive the same benefits that would have been obtained from an earlier operation.

Table 2 Statistical analysis based on the comparison of Ordinary vs DEA Groups

\begin{tabular}{llll}
\hline & $\begin{array}{l}\text { Ordinary } \\
\text { Group }\end{array}$ & $\begin{array}{l}\text { Emergency } \\
\text { Group }\end{array}$ & P Value \\
\hline Operation time (min) & $75,5(40-220)$ & $90(28-200)$ & 0,1874 \\
\hline $\begin{array}{l}\text { PO hospital stay } \\
\text { (days) }\end{array}$ & $2(1-10)$ & $3(2-12)$ & 0,002313 \\
\hline Conversion rate & $6,7 \%$ & $2 \%$ & 0,3869 \\
\hline Complications & $8,5 \%$ & $2 \%$ & 0,2352 \\
\hline Drains & $16,7 \%$ & $51 \%$ & 0,0003 \\
\hline Associated operations & $13,3 \%$ & $12,8 \%$ & 0,998 \\
\hline Cancer & $3 \%$ & 0 & - \\
\hline
\end{tabular}

Table 3 Statistical analysis based on the comparison of EDLC and D-DLC Groups

\begin{tabular}{llll}
\hline & Early-ELC & Delayed-ELC & P Value \\
\hline WBC & $11,05(3,73-28,8)$ & $9,05(2,23-15,6)$ & 0,03264 \\
\hline PCR & $1,39(0,04-45)$ & $0,66(0,08-23,23)$ & 0,1672 \\
\hline Temperature & $14 \%$ & $2(7 \%)$ & 0,5281 \\
\hline Thickened wall & $57.4 \%$ & $13(48 \%)$ & 0,4 \\
\hline Pericholecystic fluid & $17 \%$ & $2(7.4 \%)$ & 0,25 \\
\hline Distended gallbladder & $43.4 \%$ & $12(44.4 \%)$ & 0,998 \\
\hline Operation time (min) & $90(36-330)$ & $85(28-195)$ & 0,1554 \\
\hline PO hospital stay (days) & $3(2-15)$ & $3(2-8)$ & 0,6551 \\
\hline Total hospital stay & $4(2-16)$ & $10(4-16)$ & $\mathrm{p}<0,01$ \\
\hline Tasso di conversione & $5 \%$ & $0 \%$ & 0,59 \\
\hline Complications & $5 \%$ & $0 \%$ & 0,59 \\
\hline Drains & $36 \%$ & $26 \%$ & 0,3752 \\
\hline Operations associated & $8 \%$ & $15 \%$ & 0,2353 \\
\hline Cancer & $1,6 \%$ & $0 \%$ & 0,998 \\
\hline
\end{tabular}

\section{Conclusions}

In agreement with literature [8-10], we consider LC a safe and effective treatment for AC also in the elderly. This study demonstrates that in our experience LC for AC is feasible as well. The learning curve of this procedure is feasible $[11,12]$. We also believe that, whenever possible, early LC is to be preferred, above all for the significantly shortened total hospital stay. Nevertheless, the retrospective analysis of our case study, even with a smaller sample for delayed LC patients, showed that elderly patients can be operated with delayed approach and still benefit from the same advantages that would be obtained with an early operation [12-19]. In our experience, according to literature, laparoscopic cholecystectomy is a secure procedure to be performed [20-24]. We consider surgery approach

Table 4 Statistical analysis based on the Team

\begin{tabular}{llll}
\hline & Team 1-Team 2 & Team 1-Team 3 & Team 2-Team 3 \\
\hline $\begin{array}{l}\text { Operation } \\
\text { time (min) }\end{array}$ & 0,6936 & 0,6089 & 0,2759 \\
\hline $\begin{array}{l}\text { PO hospital } \\
\text { stay (days) }\end{array}$ & 0,3159 & 0,02131 & 0,09583 \\
\hline $\begin{array}{l}\text { Total hospital } \\
\text { stay }\end{array}$ & 0,9362 & 0,004337 & 0,004981 \\
\hline $\begin{array}{l}\text { Conversion } \\
\text { rate }\end{array}$ & 0,1553 & 0,6677 & 0,3896 \\
\hline Complications & 0,3823 & 0,998 & 0,998 \\
\hline
\end{tabular}


more difficult in the elderly in some cases [25] but we also considered laparoscopic approach is, in general, a safe and feasible technique in acute pathology and a safe approach also in the elderly [26].

\section{Competing interests}

The authors declare that they have no competing interests.

\section{Authors' contributions}

AGF: conception and design, interpretration of data, given final approval of the version to be published.

SE: conception and design, interpretration of data, given final approval of the version to be published.

MS: acquisition of data, drafting the manuscript, given final approval of the version to be published.

AF: acquisition of data, drafting the manuscript, given final approval of the version to be published.

SC: acquisition of data, drafting the manuscript, given the final approval of the version to be published.

GP: acquisition of data, drafting the manuscript, given the final approval of the version to be published.

SM: critical revision, interpretation of data, given final approval of the version to be published

VM: critical revision, interpretation of data, given final approval of the version to be published

\section{Declarations}

Funding for this article came from personal funds.

This article has been published as part of BMC Surgery Volume 13 Supplement 2, 2013: Proceedings from the 26th National Congress of the Italian Society of Geriatric Surgery. The full contents of the supplement are available online at http://www.biomedcentral.com/bmcsurg/supplements/13/

Published: 8 October 2013

\section{References}

1. Catani M, Modini C: Laparoscopic cholecystectomy in acute cholecystitis: a proposal of safe and effective technique. Hepatogastroenterology 2007, 54:2186-91.

2. Chung-Mau Lo, Chi-Leung Liu, Sheung-Tat Fan, Edward Lai CS, John Wong: Prospective Randomized Study of Early Versus Delayed Laparoscopic Cholecystectomy for Acute Cholecystitis. Ann Surg 2008, 227:461-467.

3. Litwin DE, Cahan MA: Laparoscopic cholecystectomy. Surg Clin North Am 2008, 88:1295-313.

4. Wilson E, Gurusamy K, Gluud C, Davidson BR: Cost-utility and value-ofinformation analysis of early versus delayed laparoscopic cholecystectomy for acute cholecystitis. Br J Surg 2010, 97:210-219.

5. Dàvila D, Manzanares C, Picho ML, Albors P, Cardenas F, Fuster E: Experience in the treatment (early vs. delayed) of acute cholecystitis via laparoscopy. Cirugia Espanola 1999, 66:233-235.

6. Bohacek L, David MD, Pace E: Advanced laparoscopic training and outcomes in laparoscopic cholecystectomy. Can J Surg 2009, 52:223-224.

7. Ballantyne GH, Ewing D, Capella RF: The learning curve measured by operating times for laparoscopic and open gastric bypass: roles of surgeon's experience, institutional experience, body mass index and fellowship training. Obes Surg 2005, 15:172-82.

8. Gill J, Booth Ml, Stratford J, Dehn TC: The extended learning curve for laparoscopic fundoplication: a cohort analysis of 400 consecutive cases. J Gastrointest Surg 2007, 11:487-92.

9. Avital S, Hermon H, Greenberg R, Karin E, Skornick Y: Learning curve in laparoscopic colorectal surgery: our first 100 patients. Isr Med Assoc J 2006, 8: 683-6.

10. Rispoli C, Rocco N, lannone L, Amato B: Developing guidelines in geriatric surgery: role of the grade system. BMC Geriatrics 2009, 9(SUPPL.1):A99.

11. Li GX, Yan HT, Yu J, Lei ST, Xue Q, Cheng X: Learning curve of laparoscopic resection for rectal cancer. 2006, 26:535-8.
12. Kauvar DS, Brown BD, Braswell AW, Harnisch MJ: Laparoscopic cholecystectomy in the elderly: increased operative complications and conversions to laparotomy. Laparoendosc Adv Surg Tech A 2005, 15:379-82.

13. Moyson J, Thill V, Simoens Ch, Smets D, Debergh N, Mendes da Costa P: Laparoscopic cholecystectomy for acute cholecystitis in the elderly: a retrospective study of 100 patients. Hepatogastroenterology 2008, 55:1975-80.

14. Polychronidis A, Botaitis S, Tsaroucha A, Tripsianis G, Bounovas A, Pitiakoudis M, Simopoulos C: Laparoscopic cholecystectomy in elderly patients. J Gastrointestin Liver Dis 2008, , 17: 309-13.

15. Kirshtein B, Bayme M, Bolotin A, Mizrahi S, Lantsberg L: Laparoscopic cholecystectomy for acute cholecystitis in the elderly: is it safe? Surg Laparosc Endosc Percutan Tech 2008, 18:334-9.

16. Majeski J: Laparoscopic cholecystectomy in geriatric patients. Am J Surg 2004, 187:747-50.

17. Stanisić $V$, Bakić M, Magdelinić M, Kolasinac $H$, Miladinović M: Laparoscopic cholecystectomy in elderly patients. Acta Chir lugos/ 2009, 56:87-91.

18. Tambyraja AL, Kumar S, Nixon SJ: Outcome of laparoscopic cholecystectomy in patients 80 years and older. World J Surg 2004, 28:745-8.

19. Aprea G, Canfora A, Ferronetti A, Giugliano A, Guida F, Braun A, Battaglini Ciciriello M, Tovecci F, Mastrobuoni G, Cardin F, Amato B: Morphofunctional gastric pre-and post-operative changes in elderly patients undergoing laparoscopic cholecystectomy for gallstone related disease. BMC Surgery 2012, 12(Suppl 1):S1.

20. Lau H, Lo CY, Patil NG, Yuen WK: Early versus delayed-interval laparoscopic cholecystectomy for acute cholecystitis: a metaanalysis. Surg Endosc 2006, 20:82-7.

21. Johansson M, Thune A, Blomqvist A, Nelvin L, Lundell L: Management of acute cholecystitis in the laparoscopic era: results of a prospective, randomized clinical trial. J Gastrointest Surg 2003, 7:642-645.

22. Lo C, Liu C, Fan ST, Lai EC, Wong J: Prospective randomized study of early versus delayed laparoscopic cholecystectomy for acute cholecystitis. Ann Surg 1998, 227:461-467.

23. Solej M, Martino V, Mao P, Enrico S, Rosa R, Fornari M, Destefano I, Ferrarese AG, Gibin E, Bindi F, Falcone A, Ala U, Nano M: Early versus delayed laparoscopic cholecystectomy for acute cholecystitis. Minerva Chirurgica 2012, 67(5):381-387.

24. Ferrarese $A$, Martino $V$, Nano M: Elective and emergency laparoscopic cholecystectomy in the elderly: early or delayed approach. BMC Geriatrics 2011, 11(Suppl 1):A14.

25. Ferrarese A, Martino V, Falcone A, Solej M, Destefano I: Perforated duodenal diverticulum: case report and short review of the literature., su Chirurgia.

26. Ferrarese A, Martino V, Nano M: Wound defects in the elderly: our experience. BMC Geriatrics 2011, 11(Suppl 1):A15.

doi:10.1186/1471-2482-13-S2-S21

Cite this article as: Ferrarese et al:: Elective and emergency laparoscopic cholecystectomy in the elderly: our experience. BMC Surgery 201313 (Suppl 2):S21.

\section{Submit your next manuscript to BioMed Central and take full advantage of:}

- Convenient online submission

- Thorough peer review

- No space constraints or color figure charges

- Immediate publication on acceptance

- Inclusion in PubMed, CAS, Scopus and Google Scholar

- Research which is freely available for redistribution 